\title{
FUNCTION OF PUBLIC SPACE IN CIKAPUNDUNG TERRACE AS NATURE TOURISM IN BANDUNG CITY
}

\author{
Karto Wijaya ${ }^{1}$, Muhammad Syahrizal ${ }^{2}$ \\ Universitas Kebangsaan, Bandung, Indonesia \\ Jln. Terusan Halimun No. 37 Bandung, 40263, Indonesia \\ Corresponding author: kartowijaya.mt@gmail.com
}

\begin{tabular}{cccc} 
& \multicolumn{2}{c}{ Article History: } \\
Received: 10 Maret & Revised: 28 Maret & Accepted: 6 April & Available online: 11 April \\
2019 & 2019 & 2019 & 2019
\end{tabular}

\begin{abstract}
The development of public space in urban forest areas as has been done on the Cikapundung Terrace has an influence on the improvement and structuring of the city of Bandung in other regions, as well as a great potential to become a natural tourist attraction. Since the city of Bandung, led by the mayor of Ridwan Kamil, has made rapid progress as a tourist city that has various tourist variants, such as nature tourism, culinary tourism, textile tourism etc., to have more than 100 popular city sights. In this case, the Cikapundung Terrace is one of the benchmarks, as an area within the city that has successfully transformed from a dirty and slum area that pollutes the surrounding environment into a tourist area that is popular and popular with people in and out of the city from various social strata. In the Urban Planning study approach, this phenomenon is a tangible manifestation of the efforts of the City Government to create a public space that is accommodating and well integrated and can be accessed by a large part of the urban community which is then referred to as Urban Space. This is in accordance with the City Government's vision and mission to preserve the environment based on the rules and regulations regarding Open Space.

The influence that is felt for the people of Bandung from the revitalization of the Cikapundung river is from the aspect of economic, social and healthy lifestyles, in the economic aspect, regional development such as this has succeeded in providing wider tourism opportunities that can involve local communities to develop independent business activities such as selling around the area, etc., in the social aspect, people interact more with each other in a positive and active communal space, and in the aspect of a healthy lifestyle, the community becomes motivated to contribute to advancing the region by maintaining cleanliness and environmental health.
\end{abstract}

Keyword: Public Space, Urban Space, Open Space

\section{INTRODUCTION}

Cikapundung river is a $28 \mathrm{~km}$ long river flow that divides the city of Bandung(Permana, 2012a). The headwater of Cikapundung river is located in the Maribaya area of West Bandung Regency, flowing south through the city of Bandung(Permana, 2012b) and empties into Citarum river in the area of Dayeuh Kolot, Bandung Regency.

During this time the Cikapundung River(Wijaya, Permana, and Swanto, 2017) is commonly used for various functions including: as a tourist attraction (Maribaya, Curug Dago, Zoo, etc.), PDAM (Indonesian regional water utility company) raw water sources, electrical energy sources managed by PT Indonesia Power Unit Saguling and as agricultural irrigation facilities (Bandung Leuwi Limus). The restoration of Cikapundung river is carried out by the City Government as an effort to improve the quality and quantity of water between the 13 other Citarum tributaries to function as a water source that can be used for various community needs. 
The Cikapundung Terrace which is the object of our research is part of the Cikapundung River, located on Siliwangi street, Hegarmanah District, Cidadap Sub-District, Bandung City, West Java 40131 and included in the North Bandung Region. This area in the 2013 Bandung City Urban Planning is a nature reserve area, in which there are some settlements (Permana, 2012a). In this area, the permit has been increasingly tightened, because this area is a city infiltration area that is very vital for urban water flow.

Cikapundung Terrace has long been known as a gathering area for creative people in the city of Bandung, such as painting, dance and so on. In this place there have been a number of art studios and several restaurants / stalls. But because of the lack of professional and responsible management, this location has become neglected and increasingly poorly maintained, people recognize this area as a haunted and slum place(Permana, 2012a). Then in 2013 the new Mayor Ridwan Kamil initiated a revitalization and conservation of various areas in Bandung to make it a more organized and commercial residential area(Permana, 2014). But not all parties feel benefited by the existence of this revitalization program, including a number of Babakan Siliwangi communities who in that year also rallied massively in a movement they named "Save Babakan Siliwangi".

Although the construction of the public area in the Babakan Siliwangi area is handled directly by the Citarum River Regional Center (BBWS), in the process the revitalization and conservation project has many obstacles. These problems include the relocation of the surrounding settlements to the project construction process which had stopped in 2014.

Public space restoration is included in the category of Urban Space development and public space structuring, because the transformation of this public space makes it an environment that has more general and diverse functions and eliminates space barriers which were initially only used by certain groups of people with limiting interests, into heterogeneous ones that can be used by people from all social strata. While the relationship with public space arrangement is that this public space is included in the urban public space area.

\section{LITERATURE REVIEW}

In general, public space can be defined by means of distinguishing the meaning of the word literally first. Public is a group of people who are not limited to anyone and space is a threedimensional formation that takes place due to the elements that limit the space (Ching, 2008). Whereas according to Bates, (1974):

Based on the ownership, public space can be classified into two types, namely:

a) Private public spaces, used by limited circles.

For example: school and office yard.

b) Public-owned public spaces, used by many people without exception.

For example: city parks, playgrounds.

Based on the place, public space can be divided into:

a) Public space inside the building (indoor public space)

b) Public space outside the building (outdoor public space)

According to Spreiregen, (1965), if the boundary space is dominated by natural elements, then the space formed is called open space. Whereas if the limiting material is dominated by artificial elements (urban mass), then the space formed is called urban space. Urban space which also has the character of open space is usually referred to as urban open space.

\section{RESEARCH METHODOLOGY}

Research on the development of this area is expected to provide an overview of the methods, facilities and various other aspects relating to public space, Urban space and public space which are key factors in the success of revitalizing and conserving a dirty and slum area so that it can become an icon of the city, the economic opportunity of the community, and the development of a healthy city lifestyle which becomes a positive image for the city of Bandung.

This study used descriptive research with the intention to describe the activities carried out in the Cikapundung Terrace area through a description that gives a clear explanation of this area, so that researchers can provide an overview to the reader. The purpose of this study was to find out the function of the public space in the center of Bandung, including the object of examination such as user activity, regional characteristics, similarities and differences in this region with others. This Cikapundung Terrace identity is a river-themed city park that is now a choice as a nature tourism destination in the city of Bandung. This research also intended to find out the potential of this region before and after the Cikapundung Terrace was built. 


\section{FINDINGS AND DISCUSSION}

\section{Profile of area location}
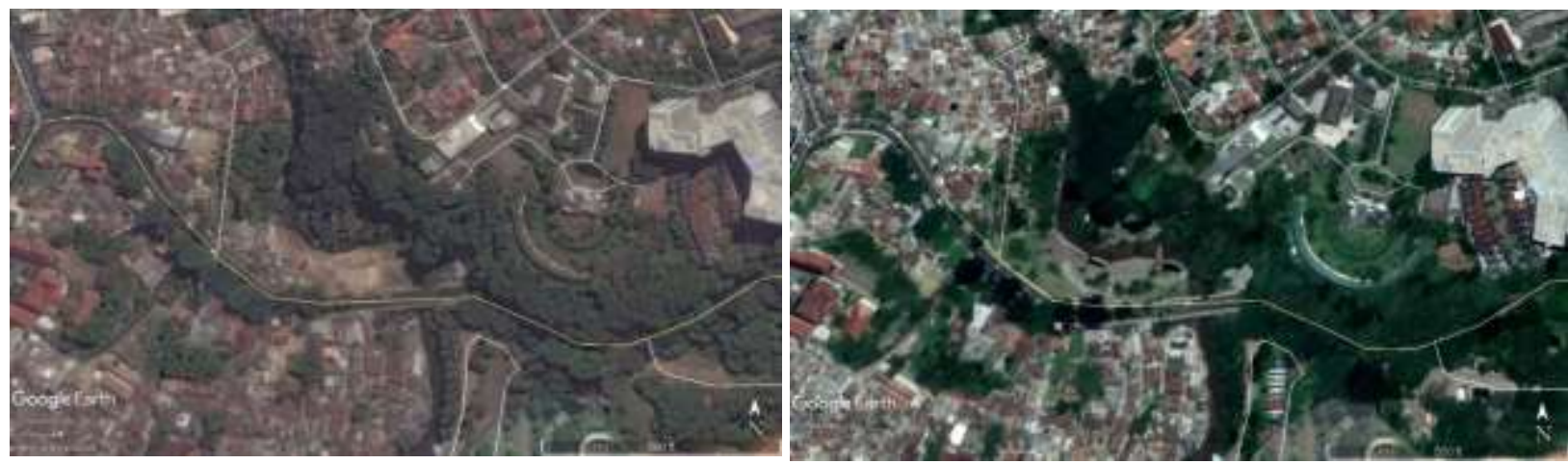

Area Map 1. Cikapundung Terrace Area in 2015 Area Map 2. Cikapundung Terrace Area in 2016

Source : Google Earth

Cikapundung River is one of the important rivers in the city of Bandung(Permana, 2014) with a length of $28 \mathrm{~km}$ sourced from the headwater in Maribaya area of West Bandung Regency and flows south through the city of Bandung and empties into the largest river, namely the Citarum river in the area of Dayeuh Kolot, Bandung Regency.
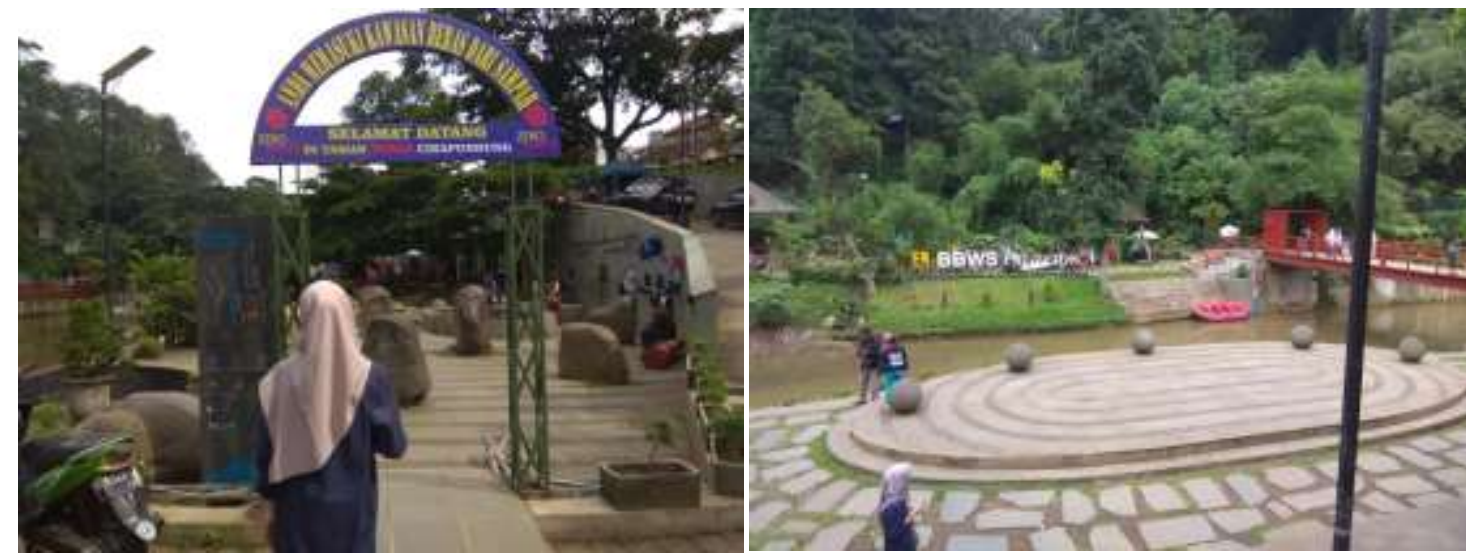

Figure 1. The Entrance of Cikapundung Terrace Area Figure 2. Cikapundung Terrace Area Landmark Source : Personal archive

During this time the Cikapundung River has been used for several purposes in the city of Bandung including:

1. As a tourist attraction in Bandung City (Maribaya, Curug Dago, Zoo, etc.);

2. The raw water source of the Bandung Regional Water Utility Company (PDAM) is 840 liters/ second which is processed at the Dago Pakar and Badak Singa processing plants;

3. Electricity sources managed by PT Indonesia Power-Unit Saguling which established installations of 3.85 MW in the Development of Hydropower Plants (PLTA) in Bengkok and Dago Pojok;

4. As a means of agricultural irrigation (Bendung Leuwi Limus), but along with the growth and development of the city, the irrigation is not functioning.

The restoration of the Cikapundung River is an initial step to improve the quality and quantity of water among the 13 other Upper Citarum tributaries to function as a water source that can be used for various community needs.

The following is the technical data of the Cikapundung River according to the Directorate General of Water Resources(Air, 2015), BBWS (River Regional Center):

- The area of the Cikapundung watershed is $154 \mathrm{~km}^{2}$

- Average rainfall: $1,500-2,400 \mathrm{~mm} /$ year

- River water discharge: $6 \mathrm{m3} /$ day 
- Land use: Plantations $53.8 \%$, Settlements $25.3 \%$, Forests $3.71 \%$, Rice fields $6.62 \%$, Shrubs 5.3\% and Empty Land 5.64\%

- Degraded land: 3,865 ha

- Run-off: 529.5 million $\mathrm{m3} /$ year

- Sedimentation: 1.023.347 ton/year
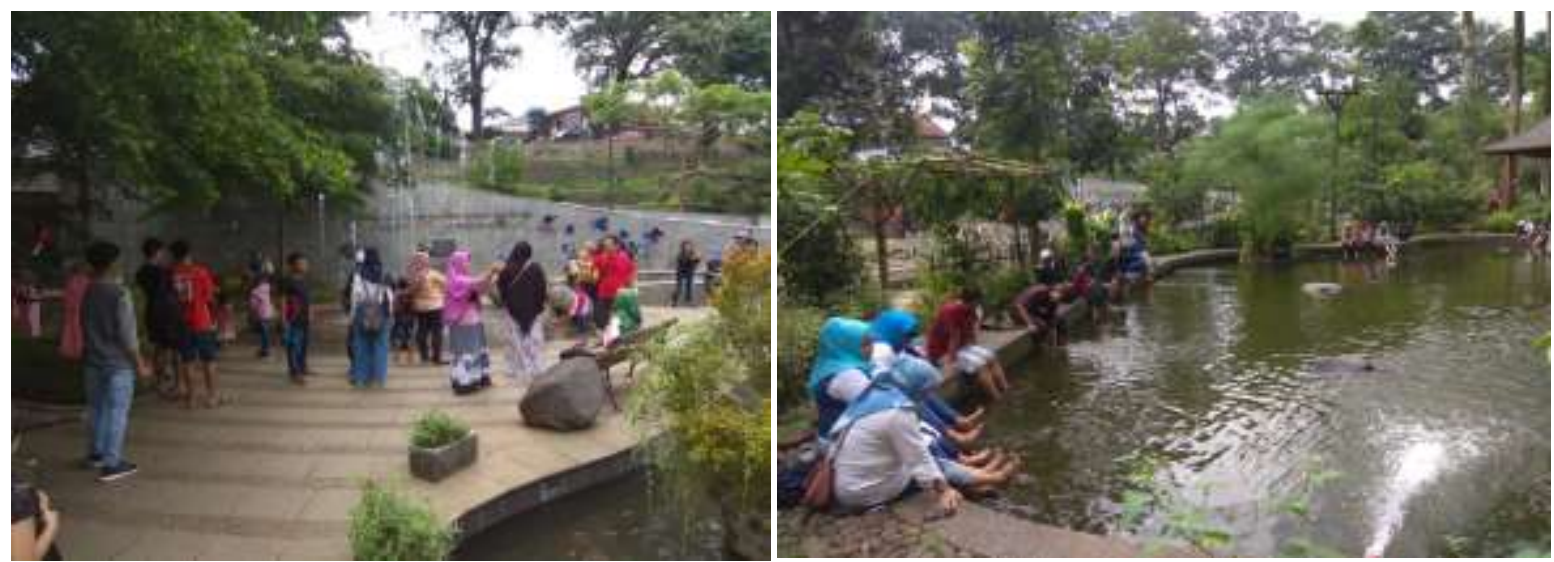

Figure 3. Spot for visitors take pictures

Figure 4. Spot for visitors socialize

Source: Personal archive

The gathering place for visitors upon first entrance entering the Cikapundung Terrace is the Dancing Fountain, where the water will light up every 1 hour, producing a beautiful fountain with LED lights as if the water is colored. This place is a favorite place for children. Figure 4 is a place where visitors can get free foot therapy, because in the pond contains fish that will eat dirts from human feet, this place is a favorite place for all visitors.

Public space in the form of open space was built in an effort to meet the various needs of urban and rural communities. Starting from the need to gather, socialize, trade, politics, and everything that is public(Hadi, 2018). The following is the function of physical public space for a city(Permana and Wijaya, 2017).

- Open space

In urban design, open space is needed in the form of land (not space) that is open and empty without any fill function. Public space is in the form of open land with public activities in it, so that it is included in the category of open space. Traditionally open space is formed from trade and defense, political systems and cultural traditions, climate, and topography.

- Public space

Seen from the very beginning, open space is a criterion for public space, because from Agora in Greece (5th century BC) to The Tokyo Town Hall Complex Citizen's Plaza (1991), are all built to accommodate public activities and needs, starting from activities such as politics, commercial, and culture.

A city will have a function as a place of recreation or health if the city has certain conditions that can attract newcomers to enjoy certain pleasures that exist in the city(Yunus, 2009; Pramudito, 2010). Social activities and interactions are interpreted as activities that require the presence of others (Zhang and Lawson, 2009). This activity can take the form of relaxed sitting and chatting, children playing in the park, as well as capturing the moment in the city park. The design of creative and themed public spaces can support the formation of activities(Permana, Sumarna, and Wijaya, 2017) and social interactions between people who visit. The existence of creative activities in city parks such as staging activities that are open to the general public can create a special attraction for the park.

Based on its scope (Matthew Carmona, 2003) public space can be divided into several typologies including: external public space. This type of public space is usually in the form of outer space that can be accessed by all people (public) such as city parks, squares, pedestrian paths, etc.

Based on its function in general it can be divided into several typologies (M. Carmona, Heath, Oc, and Tiesdell, 2008) namely: positive space. This space is in the form of public space which can be used for positive activities and is usually managed by the 
government(Gist and Halbert, 1956). The form of this space includes natural / seminatural space, public space and public open space.

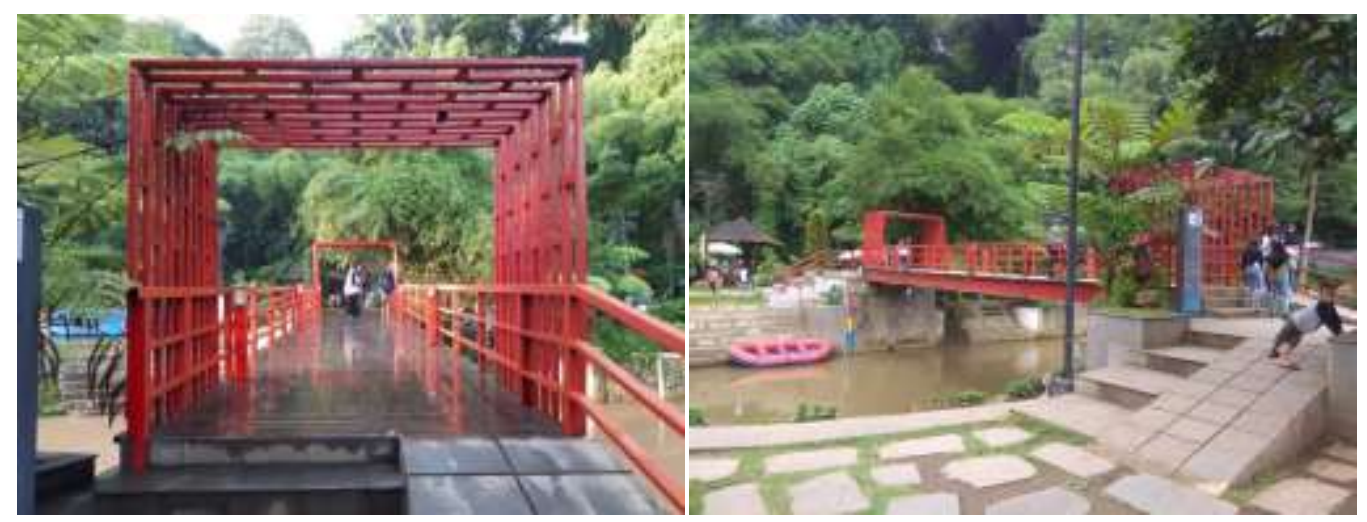

Figure 5. Landmark and Spot for picture-taking Source: Personal archive

This theme park has a landmark, namely the red bridge, which can attract people to visit. In addition, there is also a fish therapy pool that is much favored by the community, both from children to the elderly. Many places or spots favored by visitors include rafting, amphitheater, and fountains.

\section{Age group}

The age group shows that visitors to the cikapundung terrace are very diverse, ranging from children with an age range between 1-10 years with a percentage of $30 \%$, adolescents with an age range between $11-20$ years with a percentage of $40 \%$, adults with a range age between $25-50$ years with a percentage of $30 \%$.

\section{Activity / occupation}

The activity/occupation of the visitors of Cikapundung Terrace have a diverse background starting from students, housewives, employees, and traders. From the data collected there are $50 \%$ student percentages, $30 \%$ housewives, $20 \%$ employees and traders.

Based on the data above, visitors to the Cikapundung Terrace are dominated by students with an age range between 8-21 years because in the Cikapundung Terrace it has a beautiful photo spot or place. In addition, housewives prefer the place of fish therapy pools while waiting for their children to play, also provided the gazebo as a place to relax and gather.

\section{Facilities and Infrastructure}

There are several facilities and infrastructure to support activities or activities on the Cikapundung Terrace including the Parking Area, for the Parking Area itself is available for twowheeled vehicles and only a little space for four-wheeled vehicles. Other supporting facilities such as Education Room, Management Room, Indoor Mosque, outdoor Mosque, and Toilet also make this area crowded with Bandung residents and Local Tourists and Foreign Tourists. The seating facilities are very adequate, starting from wooden chairs, concrete balls, river stones, gazebos, as well as the podium in the Amphitheater area.
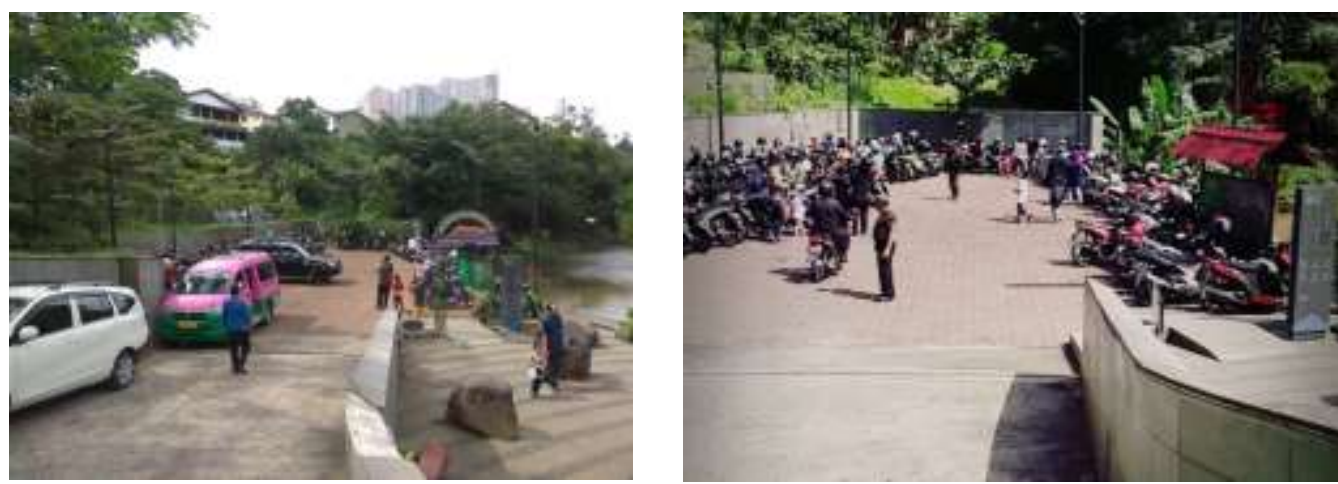

Figure 6. The Cikapundung Terrace Parking Area 


\section{Source : Personal archive}

For visitors who want to find out all the facilities available on the Cikapundung Terrace there is a Signed to find out complete information in which there is directions. Therefore, visitors can see the terrace prior to entering the Cikapundung Terrace area.

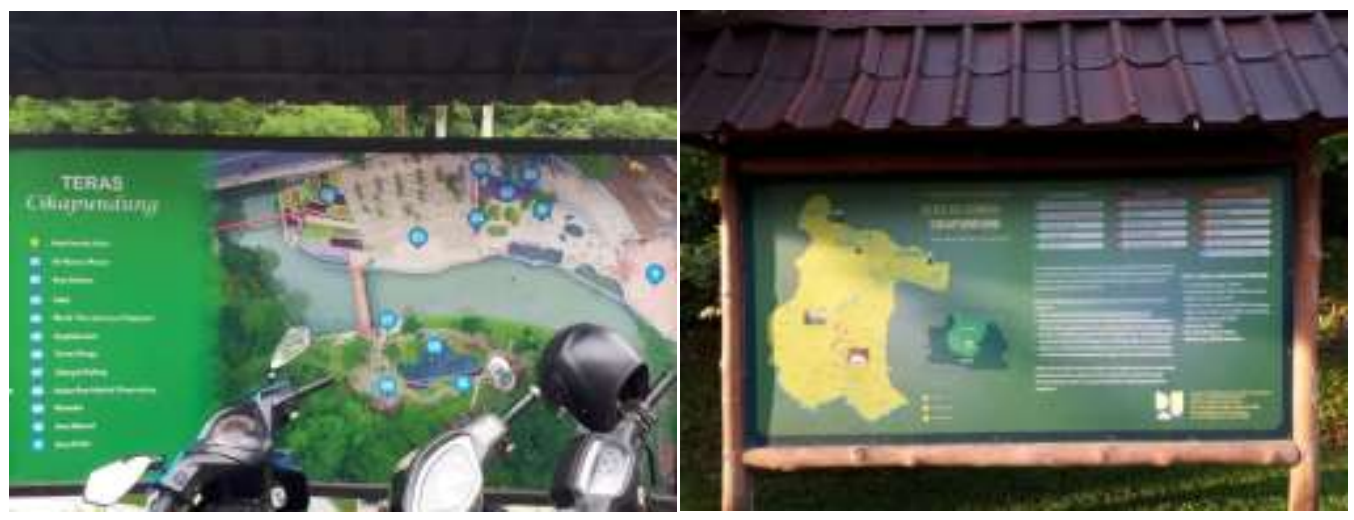

Figure 7. Floor Plan and Map of the Cikapundung Terrace Area Source : Personal archive

The Signed consists of:

1. Dancing Fountain

2. Education Area

3. Toilet

4. Mural "The Journey of Happines"

5. Amphitheater

6. Garden of Flowers

7. Tubing and Rafting

8. Cikapundung Habitat Fish Pond

9. Mosque

10. Natural Area

11. Parking area

The Cikapundung terrace area has an attraction, visitors are treated to a Dancing Fountain show. This area is designed to form a circle centered with balls made of perfectly rounded stones placed around the Fountain. The material of this Dancing Fountain floor is of Andesite Natural Stone which is built in a circle. On the surface of the floor has a rough texture so that when stepped on does not cause slipping due to slippery. This area is a favorite area for children, especially if at night the Fountain is equipped with colourful lights that are eye-catching.
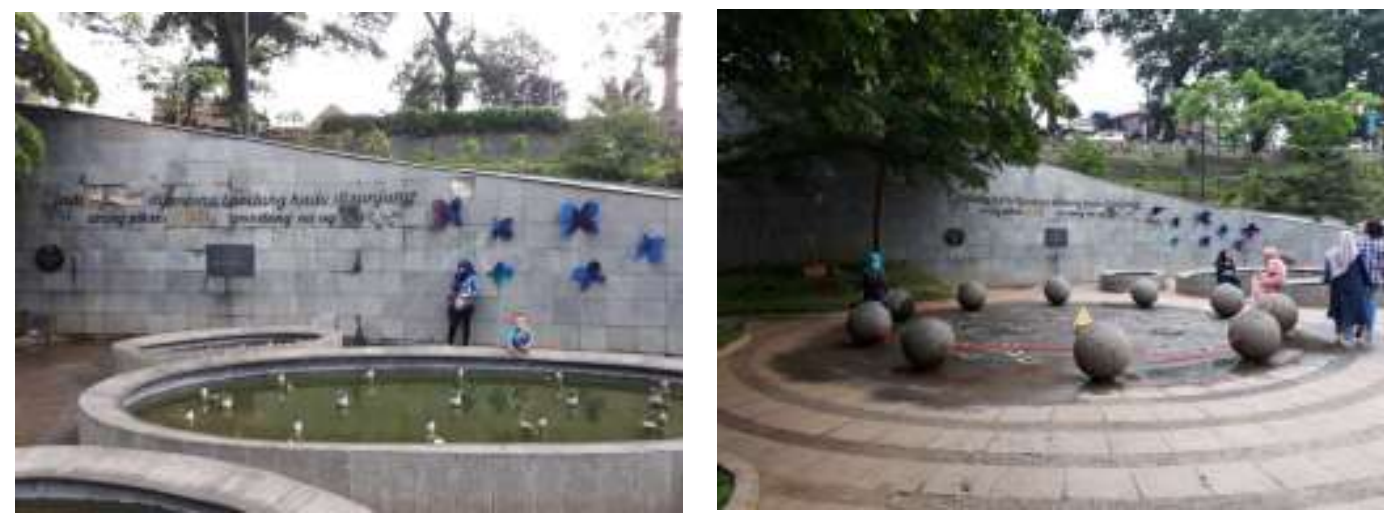

Figure 8. The Cikapundung Terrace Dancing Fountain

Source : personal archive

Then there is the Education Area available for visitors of the Cikapundung Terrace. The aim is to provide and share knowledge, especially Natural Sciences. Visitors can attend the Socialization Room adjacent to the Sclupture Area. In this place, visitors can ask anything about 
the Cikapundung Terrace area, from interesting activities to routing events that are presented every week.
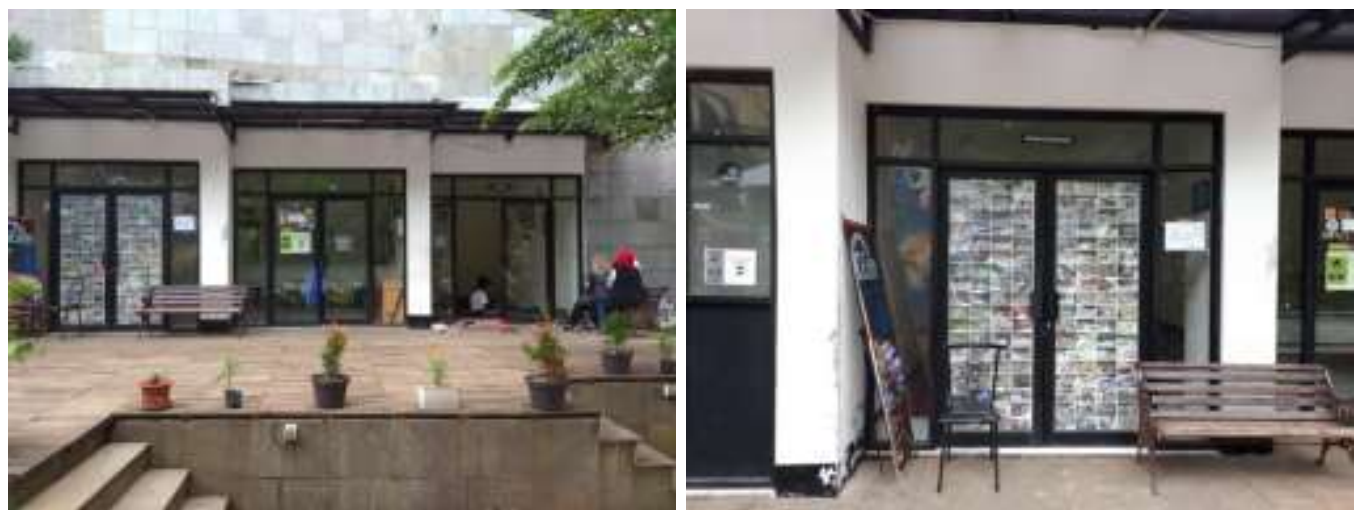

Figure 9. Room Facilities for Socialization and Supporting Facilities of Cikapundung Terrace

Source : Personal archive

In the Cikapundung Terrace area there is an Amphitheater, in Amphitheater visitors can perform themselves or more often the amphitheater is used to watch together. With the Open Plan Amphitheater concept, it is designed to form terraces which are covered by Natural Andesite Stones and to make this area lush and shady, the amphitheater also is planted with several trees with dense leaf characters. For visitors of the Cikapundung Terrace who visit the event of watching together in the Amphitheater area, a screen is provided for the usual watching activities that are held once a week.
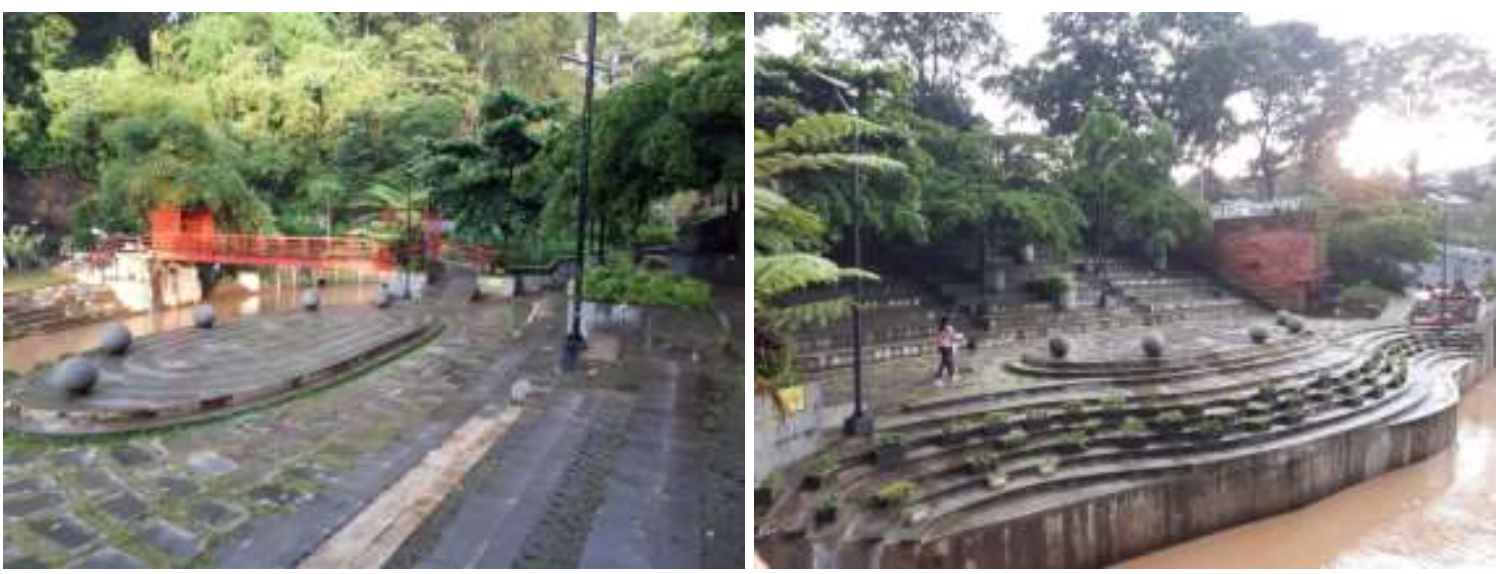

Figure 10. The Amphitheater of Cikapundung Terrace

Source : Personal archive

\section{CONCLUSION}

According to observers the function of the public space of Cikapundung Terrace has functioned as it should, provided Bandung residents places to interact, recreation, and gather together. In addition, in terms of the environment, the city of Bandung has its own added value because it has preserved one of the largest rivers in Bandung, namely the Cikapundung river. Adding natural tourist attractions, so that it can attract visitors or local and outside tourists to visit the city of Bandung which has many thematic parks and one of them is Cikapundung Terrace. The Cikapundung Terrace Restoration which is the object of our research has fulfilled the Public Space design rules outlined by Urban Planning Experts. The success of the City Government has made this Location an accessible, well-managed and integrative Public Space for the Green City Open Space arrangement. Moreover, it has a positive impact on the socio-economic life and healthy lifestyle of the local community while restoring a positive mind for the City of Bandung as an organized and attractive clean city to be visited by local and foreign tourists.

\section{ACKNOWLEDGEMENTS}

Author wants to say thank you to the residents of Babakan Siliwangi, specifically to the BBWS (Cikapundung river regional center) Cikapundung Terrace administrator who has provided data and information related to the brief history of the Cikapundung Terrace, as well as to Bandung 
residents (visitors) who have expressed their opinions regarding the Cikapundung Terrace. This research also went well because of the teamwork that took the time to conduct research about the public space of Cikapundung Terrace.

\section{REFERENCES}

Air, K. P. U. dan P. R. D. J. S. D. (2015). No Title. Jakarta: Kementerian Pekerjan Umum dan Perumahan Rakyat, Direktorat Jenderal Sumber Daya Air. Retrieved from https://sda.pu.go.id/assets/uploads/files/2355c-lakip-ditjen.-sda-2015.pdf

Bates, D. L. G. (1974). Little Rock Central High Scholl. Arkansas: National Park Service, University of Arkansas, Fayetteville, AR.

Carmona, M. (2003). Public Places- Urban Space, The Dimension of Urban Design. USA: Architectural Press.

Carmona, M., Heath, T., Oc, T., and Tiesdell, S. (2008). Public Spaces: The Management Dimension. New York: Taylor and Francis Group.

Ching, F. D. K. (2008). Bentuk, Ruang, dan Tatanan (3rd ed.). Jakarta: Erlangga.

Gist, N. P., and Halbert, L. A. (1956). Urban Society (4th ed.). New York: Thomas Y. Crowell COmpany.

Hadi, S. (2018). Ruang Publik. Retrieved from https://syulhadi.wordpress.com/my-document/ umum/komunikasi-antarbudaya/ruang-publikpublic-space/

Permana, A. Y. (2012a). Eco-architecture Sebagai Konsep Urban Development di Kawasan Slums dan Squatters Kota Bandung (pp. 1-11). Semarang.

Permana, A. Y. (2012b). Peran Ruang Terbuka Publik di Kawasan Slums dan Squatters sebagai "Ruang Ketiga" (Kasus: Kawasan Bantaran Sungai Cikapundung di Kota Bandung. In SEMINAR NASIONAL "Sustainable Urbanism" Adaptasi Perubahan Ruang Perkotaan-Pendekatan Teoritik dan Praktek (pp. 84-98). Semarang: Media Plano : Biro Penerbit Planologi UNDIP.

Permana, A. Y. (2014). Transformasi Gubahan Ruang: Pondokan Mahasiswa di Kawasan Balubur Tamansari Kota Bandung. Universitas Diponegoro. Retrieved from http://eprints.undip.ac.id/62084/

Permana, A. Y., Sumarna, N., and Wijaya, K. (2017). Membangun Kampung Kreatif melalui Kolaborasi Mahasiswa dengan Masyarakat. Kasus: Kawasan Balubur-Tamansari Kota Bandung. In Prosiding Seminar Nasional "Perencanaan Pembangunan Inklusif Desa-Kota" (pp. 51-58). Padang: Asosiasi Sekolah Perencanaan Indonesia (ASPI), Perhimpunan Ekonomi Pertanian Indonesia (PERHEPPI), dan Program Pascasarjana Universitas Andalas.

Permana, A. Y., and Wijaya, K. (2017). Spatial change transformation of educational areas in Bandung. In IOP Conference Series: Earth and Environmental Science (International Conference on Sustainable in Architecture Design Urbanism/ICSADU) (Vol. 99, p. 012029). Semarang: IOP Conference Series: Earth and Environmental Science. https://doi.org/10.1088/1755-1315/99/1/012029

Pramudito, S. (2010). "Bab II-Tinjauan Taman Rakyat sebagai Bagian dari Ruang Publik", Taman Rakyat di Yogyakarta. Retrieved from http://e-journal.uajy.ac.id/2054/3/2TA12493.pdf.

Spreiregen, P. D. (1965). Urban Design: The Architecture of Town and Cities. New York: The American Institute of Architects, MCGraw Hill Book Company.

Wijaya, K., Permana, A. Y., and Swanto, N. (2017). Kawasan Bantaran Sungai Cikapundung Sebagai Pemukiman Masyarakat Berpenghasilan Rendah (MBR) Di Kota Bandung. ARCADE, 1(2), 57-68.

Yunus, H. S. (2009). Klasifikasi Kota: Klasifikasi Kota Atas Dasar Karakteristik Fungsinya. Yoyakarta: Universitas Gadjah Mada.

Zhang, W., and Lawson, G. (2009). Meeting and Greeting : activities in Public Outdoor Spaces Outside Highdensity Urban Residential Communities, 14, 207-214. 